\title{
Integrated humification of poultry waste
}

\author{
Maryam Mushtaq ${ }^{1 *}$, M. K. Iqbal ${ }^{2}$, A. Nadeem ${ }^{3}$ and R. A. Khan ${ }^{2}$ \\ ${ }^{I}$ University of Lahore, 2. PCSIR Lahore, 3. Bagbhanpura college Lahore \\ ${ }^{2}$ Pakistan Council of Scientific \& Industrial Research (PCSIR) Lahore, Constitution Avenue, Islamabad, Pakistan \\ ${ }^{3}$ Bagbhanpura college, Lahore, Pakistan
}

Received: 15 November 2017

Revised: 16 April 2018

Accepted: 23 May 2018

DOI: http://dx.doi.org/10.3329/bjsir.v53i4.39192

\begin{abstract}
In this study effects of adding chemical and microbial agents in the humification process of poultry wastes were carried out. Chemicals and microbes play a vital role to accelerate the humification process. Salmonella and lime were applied individually to observe the variation in maturity and stability parameters like degree of polymerization (DP), C/N, humification rate (HR), humification index (HI), cation exchange capacity (CEC), and nitrate nitrogen concentration of the humified poultry wastes. Thus it was acclaimed that the microorganisms Salmonella encourage the compost formation where as humification with lime proceeded relatively with a lesser time than Salmonella. Furthermore, the decline in carbon and nitrogen ratio and increase in CEC, DP, HR, $\mathrm{HI}$, potassium and phosphorous were recognized in a higher scale in chemically treated wastes compared to that of microbial one. It was concluded that use of chemicals reduce the quantum of waste in minimum time.
\end{abstract}

Keywords: Chemical; Microbes; Compost; Humification; C/N ratio

\section{Introduction}

The soil physicochemical properties can be changed by induction of soil microorganisms and micronutrients and can increase the decomposition rate of poultry wastes (Gul et al., 2015). Under such condition acidification and ammonium volatilization process in soil increase. Various chemicals like alum, $\mathrm{NaHSO}_{4}, \mathrm{H}_{2} \mathrm{SO}_{4}$ and aluminum phosphate decrease the water soluble phosphorus and surface adsorption complexes, but increased the carbon and nitrogen mineralization rate (Hunger et al., 2004). Lime is also used to raise the $\mathrm{pH}$ of immature compost because many acids are produced during composting process which later on stabilize. The production of acids play an important role in killing the dangerous pathogens and lime adjust the $\mathrm{pH}$ of compost up to 6.5 thereby enabling a condition ideal for plant growth (Iqbal et al., 2015).

The Salmonella was isolated from poultry waste, an eminent pathogen indicator used in composting. The Salmonella spp. is very useful in stabilization of compost material. It is related to human pathogen and very important in order to evaluate the quality of stable compost to limit the health risk (Briancesco, 2008). In composting, inactivation of pathogen during the composting period can be affected by a number of mechanisms (Wilkinson, 2008).Temperature of compost is an important factor beause it effects the activity of microorganisms such as microbial metabolic rate and population structure (Iqbal et al., 2010). In composting process the microbial activity begins at ambient temperature which later on elevate the temperature of compost material in thermophilic phase. In it many non-thermos tolerant organisms are activated and it gradually decrease the microbial activity, turns cooling and results maturation of the composting mass (Steger et al., 2007).

In the process of decomposition, cation exchange capacity (CEC), humification rate (HR), degree of polymerization (DP), humification index (HI), concentration of fulvic- (FA) and humic acid (HA) increases due to conversion of lingo cellulose into humus by microbes (Ming et al., 2015; Taiwo et al., 2016).

\footnotetext{
*Corresponding author e-mail: maryammushtaq7866@gmail.com
} 
When it occurs, the ratio of carbon to nitrogen gets below 20 and this is considered as indicator of compost maturity. Through microbial activity metabolism of protein increases $\mathrm{NH}_{3}$, volatilization of which may cause the decrease in $\mathrm{NH}^{+4}-\mathrm{N}$ due to the insignificant alkaline $\mathrm{pH}$ of the compost. The large microbial population could increase degradation of biochar and diversity of microbes in the composting heaps. Fungi partially degrade biochar during the process of composting. Losses of nitrogen may occur during the composting of poultry manure due to the initial elevation of $\mathrm{NH}_{3}$ and the incidence of easily mineral able compounds of $\mathrm{N}$, like uric acid can be emitted during the early phases of composting. Decrease of $\mathrm{NH}_{3}$ volatilization is notified due to low concentration of $\mathrm{N}$ in soil amended with biochar and high carbon and nitrogen ratio. This favors the microbial immobilization of soils containing comparatively small amounts of inorganic $\mathrm{N}$ (Lehmam and Rondon, 2005). The aim of this study was to compare the humification of poultry wastes by applying chemicals and microbes and to evaluate the decomposition time also.

\section{Materials and methods}

\section{Isolation of bacteria from Poultry wastes}

Freshly collected samples of poultry waste were streaked on potato dextrose agar (PDA) plates. These plates were incubated for $48-72 \mathrm{~h}$ at $38-42^{\circ} \mathrm{C}$ without aeration. Colonies of different bacterial strains were recognized on these plates. Different species of Salmonella were separated from this culture of bacteria on agar plate.

\section{Isolation of Salmonella}

Colonies typical (pale or colorless with or without black centers) to Salmonella on the agar plates on desoxycholate Citrate Agar (DCA) and a bright red color on propylene glycol deoxycholate agar (PGDA) were cultured on the agar plates having triple sugar iron agar slants, urea agar and lysine broth and incubated at $38^{\circ} \mathrm{C}$ for $48 \mathrm{~h}$. By sub-culturing onto fresh (PGDA) plates, the purity of suspected Salmonella colonies were identified that were hydrogen sulfide positive on triple sugar iron (TSI) agar, urease negative and lysine positive. The purified Salmonella colonies were moved to agar slants by streaking and further biochemical tests were performed which included sugar, decarboxylase test and glycerol fermentation.

\section{Salmonella spp. cell culture}

\section{aMicrobial method}

Poultry waste was collected from different poultry farms and mixed with wheat straw of $0.5 \mathrm{~mm}$ in size. All apparatus used for composting process were sterilized. Experimental flasks were washed thoroughly with double distilled water (DDW) and sterilized. After adding poultry waste and wheat straw in it, the mouth of the flasks were closed by putting cotton plug in it and covered with aluminum foil. The flasks thus made ready with poultry waste, were autoclaved at $121^{\circ} \mathrm{C}$ and at $15 \mathrm{psi}$ for 15 minutes in order to kill all the microbes present in the poultry wastes. Three flasks were taken for control and three for experimental compost separately. In the experiment, initially $100 \mathrm{~g}$ of each sterilized poultry waste mixture (poultry waste: $70 \%$ and $30 \%$ wheat straw) was used. The sterilized sample mixed with $10 \%$ of broth inoculums of each Salmonella isolates, separately. Similarly sterilized raw material were mixed with different chemicals ( $\mathrm{N}, \mathrm{P}, \mathrm{K}$, alum, ammonium, nitrate) to analyze the humification of poultry waste. During composting the inoculated flasks were incubated at $38^{\circ} \mathrm{C}$.

\section{Chemical Method}

Poultry waste and wheat straw were melded in a mechanical composter of $10 \mathrm{~L}$ capacity. The composter drum $(300 \mathrm{~mm}$ long and $250 \mathrm{~mm}$ in dia) made up of $3 \mathrm{~mm}$ thick sheet of stainless steel (SS) and was fixed on an iron stand. Inside the drum, steel angles were welded horizontally to provide appropriate mixing of wastes. Simultaneously, two holes (200 and $100 \mathrm{~mm}$ ) were made both at the upper and the lower portion of the drum, respectively. With the help of SS containers, the mixed poultry waste and wheat straw were loaded into the composter and filled up to $50 \%$ of the total volume. To ensure proper mixing and aeration, the composter was run regularly $5 \mathrm{~h}$ daily at $500 \mathrm{rpm}$ by electrical gearbox. A thermocouple was fixed to monitor the regular changes in temperature after every five hours. Alum $(0.3 \%)$ was used as an inorganic additive, which was spreaded on the poultry waste mixture and homogenized in a mechanical composter in each experimental batch. Samples without additives and microbes were run and observed for the same parameters for all chemicals and microbes. Controls were done in triplicate. All the results were reported as an average. The $300 \mathrm{~g}$ samples were collected from each runs after five days intervals regularly up to sixty five days. Samples were dried at $75^{\circ} \mathrm{C}$ and passed through $2 \mathrm{~mm}$ sieve for the analysis of ash, carbon nitrogen ratio $(\mathrm{C} / \mathrm{N})$, humification index $(\mathrm{HI})$, degree of polymerization (DP) and humification rate (HR).

\section{Analytical method}

The chemical properties (C/N,HR, FA, DP, HA, HI ,CEC and ash) of the compost were verified after Iqbal et al. (2010). The micronutrient ( $\mathrm{Zn}, \mathrm{Mn}, \mathrm{Fe}, \mathrm{Cu}$, and $\mathrm{Cd}$ ) concentration of the compost were analyzed by using the Atomic Absorption Spectrophotometer ( Analytik Jena, (novAA:800). The chemical properties of the compost 
samples were anal yzed by using standard methods (Peech et al., 1962; Nelson and Sommers, 1996). The analyses of total $\mathrm{N}$ and total $\mathrm{C}$ from the experimental samples were carried out by catalytic tube combustion using the Vario Macro Elementar Analysensysteme Gmb HCHNS analyzer (S.N: 11046079) The carbon and nitrogen ratio was calculated as the quotient of total carbon over total nitrogen.

\section{Results and discussion}

Fig.1a.showed the comparison of $\mathrm{C} / \mathrm{N}$ ratio between experimental, control and chemical decomposition. As $\mathrm{C} / \mathrm{N}$ ratio was decreasing continuously in the experimental samples of control, microbial and chemical studies, chemicals were applied to poultry wastes for the purpose of decomposition. Results show further decrease in $\mathrm{C} / \mathrm{N}$ as compared to microbial values. With the raise in composting time, there was a decline in carbon and nitrogen ratio for both the composts namely, microbial and chemical (Iqbal et al., 2014). At $25^{\text {th }}$ day of decomposition $\mathrm{C} / \mathrm{N}$ starts to decrease largely as compared to microbial ratio. Chemical decomposition gives $17.86 \% \quad \mathrm{C} / \mathrm{N}$ where as microbial decomposition gives $22.89 \% \mathrm{C} / \mathrm{N}$. Maximum difference noted on the $30^{\text {th }}$ day of decomposition when microbial gave $22.06 \% \mathrm{C} / \mathrm{N}$ and chemical decomposition gave $16.04 \% \mathrm{C} / \mathrm{N}$. In poultry waste low carbon to nitrogen ratio caused the loss of $\mathrm{N}$ through $\mathrm{NH}_{3}$ volatilization (Tiquia and Tam 2002). According to (Golueke et al., 1981) carbon and nitrogen ratio less than 20 show the acceptable maturity and ratio of 15 or less is expedients. One of the most vital factors that affect the quality of compost is carbon to nitrogen ratio. In composting, a range of $\mathrm{C} / \mathrm{N}$ ratio from 25 - 30 considered ideal (Kumar et al., 2010). In composting, lower initial carbon to nitrogen ratio is helpful in increasing the amount of treated manure which also helps in increasing the loss of $\mathrm{N}$ as $\mathrm{NH}_{3}$ gas. Compost stability showed the low carbon to nitrogen ratio, while reduction in carbon showed the maturity of compost. Microbes use organic compound for their nutrition that is the main reason in reduction of $\mathrm{C} / \mathrm{N}$ ratio (Waqas et al., 2017).

The qualitative differences in microbial and chemical decompositions have been depicted in Fig.1b. The decomposition rate was high in chemical method than microbes, because microbes used the organic carbon for their energy purpose. Moreover, both treatment results showed the significant difference. During observation on $25^{\text {th }}$ day the nitrate concentration was $198.65 \mathrm{mg} / \mathrm{kg}$ and $143.06 \mathrm{mg} / \mathrm{kg}$ by chemical and microbial method respectively. This remarkable change was also observed on $50^{\text {th }}$ day of composting between these two method results i.e. microbial decomposition gives $307.68 \mathrm{mg} / \mathrm{kg}$ value of $\mathrm{NO}_{3}{ }^{-}$while chemical decomposition of $\mathrm{NO}_{3}^{-}$gives $352.54 \mathrm{mg} / \mathrm{kg}$ (Fig.1b). Nitrate is a salt and it dehydrates the surrounding

Table I. Chemical characteristics of poultry waste, experimental, control compost and wheat straw

\begin{tabular}{lccccc}
\hline \multicolumn{1}{c}{ Parameters } & $\begin{array}{c}\text { Poultry } \\
\text { Waste }\end{array}$ & $\begin{array}{c}\text { Wheat } \\
\text { Straw }\end{array}$ & $\begin{array}{c}\text { Control } \\
\text { Compost }\end{array}$ & $\begin{array}{c}\text { Chemical } \\
\text { Compost }\end{array}$ & $\begin{array}{c}\text { Microbial } \\
\text { Compost }\end{array}$ \\
\hline Moisture (\%) & 55.78 & 11.59 & 38.65 & 29.18 & 29.16 \\
$\mathrm{pH}$ & 7.8 & 6.54 & 8.02 & 8.87 & 8.42 \\
$\mathrm{Ash} \mathrm{( \% )}$ & 42.45 & 35.49 & 40.09 & 54.32 & 47.65 \\
Organic Matter (\%) & 57.55 & 64.51 & 59.91 & 45.68 & 52.35 \\
Total Nitrogen (\%) & 3.85 & 0.1 & 1.6 & 1.86 & 1.6 \\
Total Carbon (\%) & 31.44 & 35.25 & 32.73 & 24.96 & 28.60 \\
C/N ratio & 8.16 & 352.5 & 20.45 & 13.41 & 17.87 \\
Total P (\%) & 1.6 & 0.17 & 1.18 & 2.37 & 2.19 \\
Total K (\%) & 1.12 & 0.06 & 2.33 & 2.21 & 2.11 \\
Total Sulphur (\%) & 0.27 & 0.39 & 0.21 & 0.24 & 0.17 \\
Total Hydrogen (\%) & 6.8 & 1.7 & 4.3 & 3.34 & 3.28 \\
$\mathrm{Zn}(\mathrm{mg} / \mathrm{kg})$ & 21.43 & 0.07 & 11.46 & 16.53 & 16.47 \\
$\mathrm{~Pb}(\mathrm{mg} / \mathrm{kg})$ & 0.53 & 0.08 & 0.18 & 1.34 & 0.28 \\
$\mathrm{Mn}(\mathrm{mg} / \mathrm{kg})$ & 1.15 & 0.09 & 0.12 & 1.64 & 1.51 \\
$\mathrm{Cu}(\mathrm{mg} / \mathrm{kg})$ & 0.54 & 0.15 & 0.37 & 0.56 & 0.40 \\
\hline
\end{tabular}



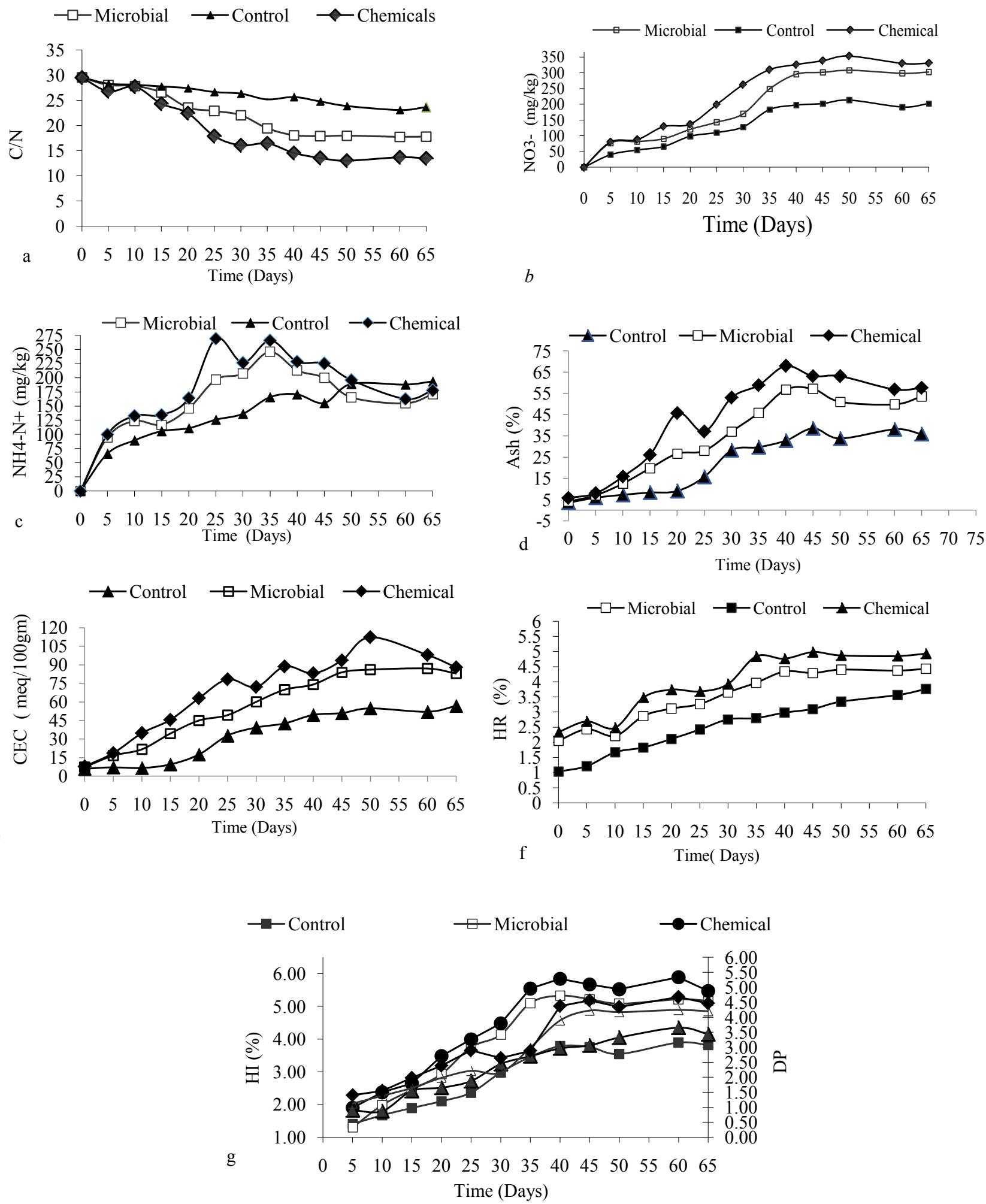

Fig. 1. Comparison of chemical and microbial methods of composting for poultry waste with time (a) $\mathrm{C} / \mathrm{N}$

(b) Nitrate (c) ammonia (d) ash (e) CEC (f) HR (g) HI \& DP 
soil, as well as it burns up the OM in soil because of being very strong oxidizer (Zhen et al., 2014). $\mathrm{NH}_{3}$ volatilization may cause decline in $\mathrm{NH}_{4}^{+}-\mathrm{N}$ that indicates the increase in $\mathrm{NO}_{3}{ }^{-} \mathrm{N}$. The temperature rise in compost may cause the loss in $\mathrm{NH}_{4}^{+}-\mathrm{N}$ and rise of $\mathrm{NO}_{3}{ }^{-}-\mathrm{N}$ may help to plant for uptake of nitrogen for plant growth. In sewage sludge the ammonia concentration decrease with time due to decomposition of nitrogenous waste (Yuan et al., 2015). Increased content of $\mathrm{NO}_{3}^{-}$than $\mathrm{NH}^{+}-\mathrm{N}$ shows the process of composting has been performed under appropriate aeration (Maria Gomez-Brandon et al., 2008). The application of chemicals and Salmonella to decompose the poultry waste showed maximum achievements in chemical method. On $10^{\text {th }}$ day, the ammonia released was $134.34 \mathrm{mg} / \mathrm{kg}$ where as 117.09 $\mathrm{mg} / \mathrm{kg}$ were released for microbial method. It was 13 percent less than chemical method. This pattern did prevail throughout the composting but at the end of the process, there no significant difference was observed (Fig.1c). The decrease of ammonia was due to the volatilization at high $\mathrm{pH}$ and temperature (Guo et al., 2012).

Fig. 1d depicted the comparison of control and microbial and chemical treatments on the same day of composting samples. At $5^{\text {th }}$ day of decomposition, no significant difference was seen among the samples. But as the process of composting proceeded the degree of decomposition increased gradually (Fig.1d). After 40th day, the percentage of decomposition of ash increases in chemical as compared to microbial samples. Ash and organic matter related inversely to each other. High organic matter content results low ash (Waqas et al., 2017). Higher microbial activities give highest rate of decomposition. Furthermore, the ash content is an additional sign of decomposition process that showed a high degree of decomposition.

On the 25th day of decomposition, CEC values in control, microbial and chemically treated samples were 32.76, 49.32 and $78.36 \mathrm{meq} / 100 \mathrm{~g}$, respectively (Fig.1e). The values were increasing with composting time. Increase in CEC during composting occurs because of aggregation of negatively charged materials such as phenolic hydroxyl and carboxyl groups (Harada and Inoko, 1980; Gao et al., 2010). Microbial alteration of lingo cellulose into humus can also cause increase in CEC (Iqbal et al., 2010).

The decomposition of poultry waste is a humification process indeed, where the production of fulvic acid initially increased compared to humic acid. The concentration of the latter increased as the composting process move forward whereas the fulvic acid decreased. The humification rate depends upon the nature of waste, moisture, chemical reaction and polymerizing agent. As the humification rate (HR) increases the humification index (HI), the degree of polymerization (DP)is also increased. They are directly proportional to each other. The microbial activity results are not significant than chemical. Chemicals enhanced the decomposition rate than microbes because it raised the $\mathrm{pH}$ and temperature of the process. On 5th day of decomposition, HR value of control, microbial and chemically treated samples showed 1.21, 2.43 and 2.69\%, respectively. Significant difference can be seen on the 35 th day of decomposition when the HR values increased to 4.84, 3.97 and $2.80 \%$ respectively in control, microbial and chemically treated samples (Fig-1f). Moreover, the same observation was observed in HI and DP (Fig-1g). The results of the present study are in agreement with Iqbal et al. (2015).

\section{Conclusion}

The addition of wheat straw reduced the moisture of poultry waste which enhanced the humification process of the waste. The addition of alum increased the humification rate than Salmonella and reduces the time for decomposition. All the humification parameters were correlated with each other and the present findings can be applicable on other wastes also.

\section{References}

Briancesco R (2008), Assessment of microbiological and parasitological quality of composted wastes: health implications and hygienic measures, Wast Manag and Res. 26: 196-202.

Gao MB, Li A, Yu F, Liang L, Yang Y and Sun Y (2010), The effect of aeration rate on forced-aeration composting of chicken manure and sawdust, Bioresour Tech. 101: 1899-1903.

Golueke CG (1981), Principles of biological resources recovery, Bio Cycle. 22: 36-40.

Gul S, Whalen JK, Thomas BW, Sachdeva V and Deng H (2015), Physico-chemical properties and microbial responses in biochar-amended soils: Mechanisms and future directions, Agricul Eco Envir. 206: 46-59. DOI: org/10.1016/j.agee.2015.03.015

Guo R, Li G, Jiang T, Schuchardt F, Chen T, Zhao Y and Shen. $Y$ (2012), Effect of aeration rate, $\mathrm{C} / \mathrm{N}$ ratio and moisture content on the stability and maturity of compost, Bioresour Technol. 112: 171-178. DOI: org/10.1016/j.biortech.2012.02.099 
Harada. Y and A Inoko (1980), The measurement of the cation-exchange capacity of composts for the estimation of the degree of maturity, Soil and Scienti Plan Nutrit. 26: 127-134.

Hunger S, Cho H, Sims JT and Sparks DL (2004), Direct speciation of phosphorus in alum-amended poultry waste: Solid-state 31P NMR investigation, Environ and Sci Tech. 38: 674-681.

Iqbal MK, Khan RA, Nadeem A and Hussnain A (2014), Conjunctive and mineralization impact of municipal solid waste compost and inorganic fertilizer on lysimeter and pot studies, Envir Technol. 35: 487-98. DOI: $10.1080 / 09593330.2013 .833641$

Iqbal MK, Shafiq T, Hussain A and Ahmad K (2010), Effect of enrichment on chemical properties of MSW compost, BioresourTechnol. 101: 5969-5977.

Iqbal MK, Khan RA and Nadeem A (2015), Optimization of Process Parameters for Kitchen Waste Composting by Response Surface Methodology, Int Jour of Envir Sci and Tech. 12: 1759-1768.

Kumar M, Ou L, Yan J and Lin G (2010), Co-composting of green waste and food waste at low $\mathrm{C} / \mathrm{N}$ ratio, Wast Manag. 30: 602-609.

Lehmam J and Rondon M (2005), Bio-char soil management on highly weathered soils in he humid tropics In: Biological Approaches to Sustainable Soil Systems, Eds. Uphoff N, Taylor and Francis Group, CRC Press, pp 517-530.

Marıa Gomez-Brandon C, Lazcano and Domınguez J (2008), The evaluation of stability and maturity during the composting of cattle manure, Chemosp. 70: 436-444.

Ming C, Piao X, Guangming Z, Chunping Y, Danlian H and Jiachao Z (2015), Bioremediation of soils contaminated with polycyclicaromatic hydrocarbons, petroleum, pesticides, chlorophenols and heavy metals by composting: Applications, microbes and future research needs, Biotechnology Advances. Biotechnol Advan. 33(6): 745-755.

Nelson DW and Sommers LE (1996), Total carbon organic carbon and organic matter In: Method of soil analysis, Part 3: Chemical methods. Eds. Sparks DL, Page AL, Helmke PA, Loeppert RH and Soltanpour PN, Tabatabai MA, Johnston CT, Sumner ME, Agronomy No. 5. SSSA Book Series, Madisonp, pp 961-1010.

Peech M, Cowden RL and Baker JH (1962), A critical study of the $\mathrm{BaCl}_{2}$-triethanoamine and the ammonium acetate method for determining the exchangeable hydrogen content of soils, Soil SciSoci of Ameri Proceed. 26: 37-40.

Steger K, Jarvis Å, Vasara T, Romantschuk M and Sundh I (2007), Effects of differing temperature management on development of Actinobacteria populations during composting, Res in Microbiol. 158: $617-624$.

Taiwo AM, Oyedepon JA, Ojekunle ZOM, Alo O, Oyeniran AA, Onalaj OJ, Ogunjimi D and Taiwo OT (2016), Bioremediation of industrially contaminated soil using compost and plant technology, Jour of Hazard Mater. 304(5): 166-172.

Tiquia SMN and Tam NFY (2002), Characterization and composting of poultry waste in forced-aeration piles, Proc biochem. 37: 869-880.

Waqas M, Nizami A, Aburiazaiza S, Barakat MA, Ismail IMI and Rashid MI (2017), Optimization of food waste compost with the use of biochar, Jour of Envir Manage. 216: 1-2. DOI: org/10.1016/ j.jenvman.2017.06.015

Wilkinson KG, (2008), The biosecurity of on-farm mortality composting, Jour of Appl Microbiol. 102: 609-618.

Yuan H, Lu T, Huang H, Zhao D, Kobayashi N and Chen Y (2015), Influence of pyrolysis temperature on physical and chemical properties of biochar made from sewage sludge, Jour of Analyt and Applpyrol. 112: 284-289.

Zhen Z, Liu H, Wang N, Guo L, Meng J, Ding N, Wu G, Jiang G (2014), Effects of Manure Compost Application on Soil Microbial Community Diversity and Soil Microenvironments in a Temperate Cropland in China, PLoS One. 9(10): 108-555. 